\title{
Enhance Strategy Promotion University of Medan Area to Increasing the Number of New Students during the COVID-19 Pandemic
}

\author{
Muhammad Al Fikri \\ Lecturer of Faculty Communication, Universitas Islam Negeri North Sumatera (UINSU), Medan, North \\ Sumatera, Indonesia
}

\begin{abstract}
Private and State Universities are still faced with competition between universities to increase the number of students especially during the Covid 19 period. This research aims to analyze the effect of each of the variables of e-service quality, e-satisfaction, positive Word of Mouth / WoM, either directly or indirectly. Data were collected from 200 students from one of the best private universities in North Sumatra (Medan), and processed using Structural Equation Modeling / SEM. From the results of data processing, all tested hypotheses can be accepted, and research found that to encourage positive WoM, PTS must be sensitive to the creation of student satisfaction. Positive WoM can be an effective advertising promotion tool for PTS to get new student candidates through existing student recommendations. In addition, to increase e-customer satisfaction, PTS is required to always improve service quality that is delivered through online services.
\end{abstract}

Keywords: e-service quality, e-customer satisfaction, positive WoM, private universities.

\section{INTRODUCTION}

Entrepreneurship

or

entrepreneurship was originally a developed concept in the sociology and psychology traditions. At the beginning of the century 18th, Richard Cantillon, Irish-born scholar big companies in France, stated that entrepreneurship is a function of riskbearing. One the following century, Joseph Schumpeter introduced the function of innovation as a powerful inner force of entrepreneurship. Since then, the concept of entrepreneurship is an accumulation of the function of courageto bear risk and innovation (Siswoyo, 2009).

Entrepreneurship is a process of creativity and innovation that has a high risk for generate added value for products that are beneficial to society and bring prosperity to entrepreneurs. Entrepreneurship is the ability to see and assess business opportunities as well ability to optimize resources and take actions and risks to succeed in his business. Based on this definition entrepreneurship it can be learned by every individual have a desire, and are not just dominated talented individuals only.

Entrepreneurship is the right choice for individuals who are challenged to create work, not looking for work.

- According to William Danko: "An entrepreneur (entrepreneur) has 4 opportunities times greater to be a millionaire".

- According to FORBES magazine: " $75 \%$ of 400 people America's richest businessman is an entrepreneur".

- The facts prove that many successful entrepreneurs have started small businesses (Siswoyo, 2006).

Entrepreneurs are those who are brave in turning ideas into reality. According to Joseph Schumpeter, the entrepreneur is a person who perceives an opportunity and creates an organization to pursue it (Bygrave, 1994: 2). Entrepreneurs are people who see opportunities, create an 
organization to take advantage of opportunities, Based on this definition, personality an entrepreneur is identified by several researchers (Siswoyo, 2006) as follows.

- Desire for responsibility, which is to have a taste big responsibility for that business just started.

- Preference for moderate risk. Entrepreneurs take more risks into account. Entrepreneurs see business opportunities based on knowledge, their backgrounds, and experiences.

- Confidence in their ability to succeed. Entrepreneurs often have selfconfidence tall one. A study conducted by the National Federation of Independent Business (NFIB) suggests a third of entrepreneurs feel you have a $100 \%$ chance of being successful.

- Desire for immediate feedback. Entrepreneur want to know how people respond other about the way they're running, and for that, they are delighted to receive input from others.

- High level of energy. Entrepreneurs are impressed has greater energy in comparison with most people.

- Future orientation. Entrepreneurs are endowed good ability in seeing a opportunity.

This is a challenge for private universities (especially in Medan as the 3rd largest city in Indonesia) to compete for new student candidates. The promotion strategy and improvement of campus facilities are still the mainstay of PTS to increase the number of qualified applicants and new students (HTTP: // www.nasional.kompas.com). Currently, many companies rely on positive WoM as an important advertising promotion tool for their companies, including PTS (Rezvani and Safahani, 2016). For companies, encouraging new sales through consumer recommendations to other consumers/ Word of mouth / WoM is a powerful, positive promotional tool that benefits the company (Sanayei and Jokar, 2013) because positive WoM was found nine times more effective as a corporate advertising promotion tool compared to traditional advertising (Mazzarol et al., 2007). However, for creating positive WoM, depending on the creation of customer/customer satisfaction satisfaction and service quality provided (Rezvani and Safahani, 2016). To improve service quality, many private universities answer through increasing campus facilities by using online services/e-service quality (http://www.kompas.com). Sellers with good quality online websites, more trusted compared to a seller with a good reputation but quality online bad websites (Gregg and Walczak, 2010). Service quality and customer satisfaction is a closely related concept. According to Zeithaml and Bitner (2003), customer satisfaction is a broader concept of service quality. In relationship marketing, satisfaction is the main determinant of the relationship between customers and service providers (Leverin and Liljander, 2006).

\section{LITERATURE REVIEW}

The use of technology in providing services / electronic service to consumers can create value in the services provided by the company, namely by ease of communication between consumers and producers and efficiency of delivery products and services to consumers (Oliveria et al, 2002; Liljandera et al, 2006). Electronic service is a service using an electronic network such as the internet, where the success of the service depends on the high and low evaluation consumers of the quality of service provided through electronic networks, in a virtual / e-service quality market (Santos, 2003). Improved service quality that is delivered can help companies create higher e-customer satisfaction (Ho and Lee, 2007; Kaura et al., 2015).

Besides Therefore, high e-service quality can influence customer behavior positive recommendation about the company to others / positive WoM (Carlson and O'Cass, 2010; Sanayei and Jokar, 2013). Key factors for evaluating service quality 
are (1) efficiency, (2) system availability, (3) fulfillment, and (4) privacy. (Sanayei and Jokar, 2013).

Electronic customer satisfaction Ecustomer satisfaction refers to the level of pleasure and satisfaction of consumers based on consumer experience in shopping electronically (Lee and $\mathrm{Wu}, 2011$ ). Bressoles et al., (2014) say that e-customer satisfaction is influenced by different online attributes thus has different effects. The relationship between e-service quality and e-customer satisfaction is stronger if consumers have few technical problems with the services provided (Black et al., 2014).

Furthermore, the creation of high ecustomer satisfaction can be the basis the formation of WoM recommendations that are beneficial to the company (Gera, 2011; Sanayei and Jokar, 2013).

WoM is communication between consumers about the company's products and services where no specific purpose of the communication is carried out. Positive WoM refers to good or positive recommendations from one person to another about products, services, or company brands (Datta et al., 2005). In increasing competition strict, efforts to provide superior service quality and create customers.

High perceived satisfaction is very important for marketers, because customer satisfaction which is high in the end will have an impact on WoM (Amin et al., 2016). Anderson and Srinivasan (2003), stated that when customers are satisfied with the quality services provided, it will lead to increased customer loyalty, thus increasing customer intention to recommend company services. Several studies have also found an indirect effect on e-service quality positive WoM through e-customer satisfaction (Amin et al., 2016; Sanayei and Jokar, 2013; Wilkins, 2010).

The Coronavirus (COVID-19) has hit a large number of countries and has turned out to be even worse than critical economic, strategic, and political problems around the world. The coronavirus outbreak has impacted and is still affecting all industries, including the use of information and communication technology. The social distancing guidelines proposed by respective governments and health departments to the public have resulted in the closure of schools and businesses and left the public baffled by an unprecedented level of change. Learning online and working from home (WFH) are ways to mediate the problem for some communities, but others may not be as fortunate. The development of information technology which is increasingly rapid in the current era of globalization cannot be avoided anymore its impact on the world of education. Global demands require the world of education to always and constantly adapt technological developments to efforts to improve the quality of education, especially adjusting the use of information and communication technology for education, especially in the learning process.
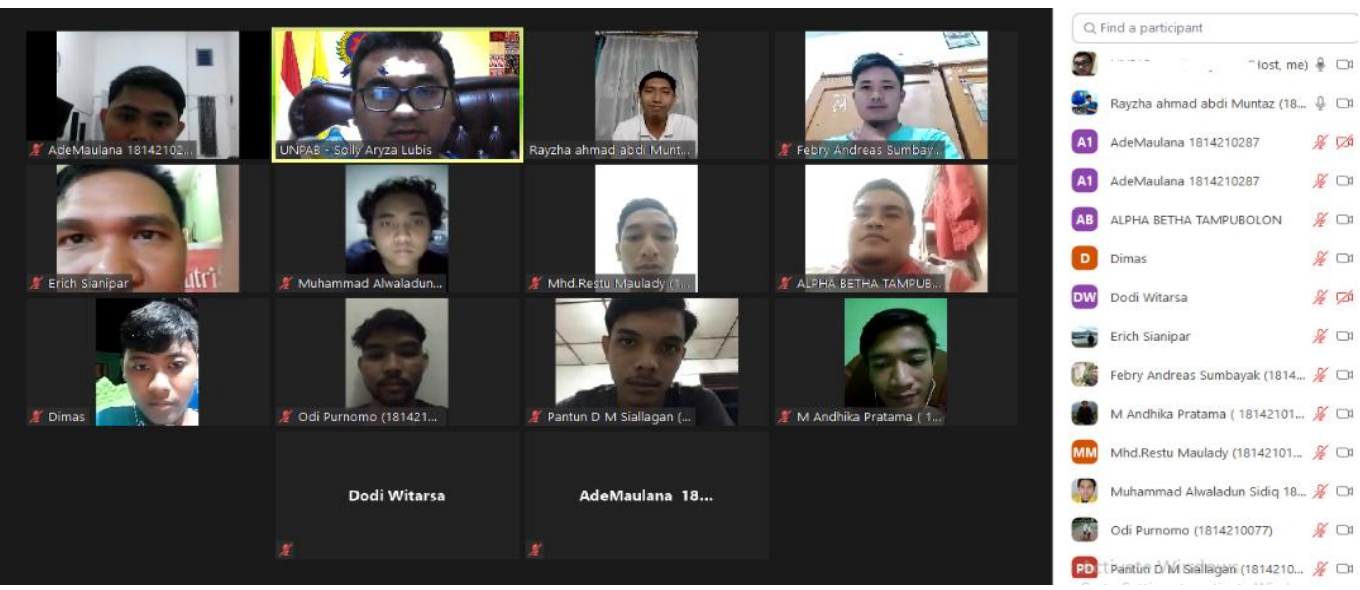

Figure 1. Study Even Covid 19 


\section{METHOD OF RESEARCH}

The research conducted aims to test the hypothesis. Collected data is primary data about the profile of respondents and data related to the research variable. There are 3 variables to be collected as measured by using measuring instruments in the form of dimensions and several statement items, namely:

(1) e-service quality, as measured by 4 dimensions and 15 statement items adapted from Sayanei and Jokar (2013),

(2) e-customer satisfaction, measured by 5 statement items adapted from Amin et al., (2016),

(3) Positive WoM, as measured by 3 items statement adapted from Sayanei and Jokar (2013). Besides, all the items The statement is given a choice of answers using a 5 point Likert scale, namely from $1=$ Strongly Disagree to $5=$ Strongly Agree. Before being collected, all measuring instruments are tested in advance to ensure that the measuring instrument is used valid and reliable. From the test results using the method confirmatory factor analysis, obtained a factor loading value> 0.6 which means all items valid/suitable statement to measure each variable. Besides that, with the method of internal consistency reliability, the Cronbach's coefficient alpha value was obtained for each variable> 0.6 , which means each variable used in reliable / consistent research.
Furthermore, data were collected from 200 students who came from the once best private universities in Medan out of the 10 best private universities in Indonesia in 2015 according to Tempo's version (http://tempo.co.id), namely: (University Medan Area). Selected students as samples in each PTS as many as 50 sixth semester students using a purposive sampling technique. The students at 4 private universities showed relatively homogeneous results, where the majority were women, came from high school in North Sumatera, aged 19-21 years and spending an average of Rp. 2,000,000 per month.

To analyze data about the research variables using the method Structural Equation Modeling, which requires goodness of fit model test to ensure in advance that the data collected fits the model formed. With the testing criteria Prob. $=0.000 ;$ TLI $=0.957 ;$ NFI $=0.909$; RMR $=0.032$; and RMSEA $=0.097$, where these values meet the cut-off values required, it can be concluded that the model formed is fit.

\section{ANALYZE AND RESULTS}

Hypothesis testing can be continued after the model formed is known to be fit. Test results The research hypotheses are summarized in the following table:

Table 1. Hypothesis Testing Results

\begin{tabular}{|l|l|l|l|l|}
\hline Hypothesis & $\boldsymbol{\beta}$ (Regression weight) & p-value & Conclusion & Decision \\
\hline $\begin{array}{l}\text { H1: There is a positive influence } \\
\text { e-service quality towards } \\
\text { e-customer satisfaction. }\end{array}$ & 0,423 & 0,000 & H0 Rejected H1 Supported & H0 Rejected H1 Supported \\
\hline $\begin{array}{l}\text { H2: There is a positive influence } \\
\text { e-customer satisfaction } \\
\text { against positive WoM. }\end{array}$ & 0.968 & 0,000 & H0 Rejected & H2 Supported \\
\hline $\begin{array}{l}\text { H3: There is a positive influence } \\
\text { e-service quality towards } \\
\text { positive WoM. }\end{array}$ & 0.329 & 0.014 & H0 Rejected & H3 Supported \\
\hline $\begin{array}{l}\text { H4: There is a positive influence } \\
\text { e-service quality towards } \\
\text { positive WoM through } \\
\text { e-customer satisfaction. }\end{array}$ & 0.409 & 0.000 & H0 Rejected & H4 Supported \\
\hline
\end{tabular}

Based on Table 1, it can be seen from the results of the $\mathrm{H} 1$ test that there is a positive effect of service quality on ecustomer satisfaction $(\beta=0.423 ; \mathrm{p}$-value $=$
0.000). Research findings H1 supports research using different dimensions of eservice ratings quality, but the results of this study support previous research, because of 
e-service quality relates to consumer perceptions about the experience where during there is an online purchasing process, consumers do not get significant problems with the electronics used, and find the contribution of e-service quality to overall e-customer satisfaction.

Likewise for the results of $\mathrm{H} 2$ and $\mathrm{H} 3$ tests, where there is a positive effect of customer satisfaction on positive WoM ( $\beta=$ 0.968; $\mathrm{p}$-value $=0.000$ ) and a positive effect. e-service quality towards positive WoM $(\beta=0.329 ; p$-value $=0.014)$. H2 test results explain that satisfaction with the level of continuous interaction with the company website will be spur positive WoM. Likewise, the $\mathrm{H} 3$ test results also support the finding that E-service quality is a matter important, because it is a company asset, namely as the most basic thing that is sought by consumers because it will add value and determines whether the consumer will continue to use the company's services in the future and recommend them to others.

Furthermore, for the indirect test of $\mathrm{H} 4$, it was also found that the positive effect of e-service quality on positive WoM through e-customer satisfaction $\beta=0.409$; $\mathrm{p}$-value $=0.000)$, where e-customer satisfaction plays a role in mediating the relationship between e-service quality and positive WoM. This also supports research. Every company should focus more on applying a holistic approach to develop relationship marketing, not just create service providers quality, but includes creating customer satisfaction which will encourage creation of positive WoM.

\section{CONCLUSION}

The study results found direct and positive effects: (a) e-service quality on ecustomer satisfaction, (b) e-customer satisfaction with positive WoM, and (c) eservice, quality against positive WoM. However, research has found an indirect effect and stronger, where e-customer satisfaction plays a role in driving its creation the effect of e-service quality on positive WoM. Therefore, the study carried out implies that PTS managers must sensitive to the satisfaction of each student because if students are satisfied, they can be positive WoM for prospective new students, or in other words students, It can be promoted as an effective advertising promotion tool to increase prospects new students. However, student satisfaction can only be achieved if PTS improve service quality that it delivers through online innovation, because the use of technology can increase the effectiveness and efficiency of the company in serve the market, namely, by improving services online that can encourage the creation of student satisfaction with the campus. For the next research, it is recommended:

(1).to research PTS in other areas facing the same problem which might result in different findings,

(2).research on relatively the same services, such as high school seniors that may encounter problems the same thing, and

(3). adding the concept of customer value, customer trust, customer commitment, and customer engagement as a comprehensive approach to relationship marketing.

\section{Acknowledgement: None}

\section{Conflict of Interest: None}

\section{Source of Funding: None}

\section{REFERENCES}

1. Amin, M., Isa, Z., Fontaine, R., 2013, Islamics Banks: Contrasting The Drivers of Customer

2. Satisfaction on Image, Trust, and Loyalty of Muslim and non-Muslim Customers in Malaysia, International Journal of Bank Marketing, vol 31 no 2, 79-97.

3. Anderson, R.E., Srinivasan, S.S., 2003, E-Satisfaction and E-Loyalty: A Contingency Framework, Psychology \& Marketing, vol 20 no 2, 123-138.

4. Barnes, S. J., Vidgen R. T., 2006, Data Triangulation and Web Quality Metrics: 
A Case Study in E-Government, Information and Management, vol 43 no $6,767-777$

5. Baykal, B., 2016, The Effect of EService Quality on Customer Perception, International Journal of Management and Applied Science, vol 2 no 1, 141-146.

6. Black, H.G, Childers, C.Y., Vincent, L.Y., 2014, Service Characteristics, Impact on Key Service Quality Relationships: A Meta-Analysis, Journal of Services Marketing, vol 28 no 4, 276291.

7. Bressoles, G., Durrieu, F., Senecal, S., 2014, A Consumer Typology Based on E-Service Quality and E-Customer Satisfaction, Journal of Retailing and Consumer Services, vol 21 no 6,889896.

8. Carlson, J., O'Cass, A., 2010, Exploring the Relationships Between E-Service Quality, Satisfaction, Attitudes and Behaviours in Content-Driven E-Service Web Sites, Journal of Services Marketing, vol 24 no 2, 112-127.

9. Casalo, L. V., Flavián, C., Guinalíu, M., 2008, Promoting Consumer's Participation in Virtual Brand Communities: A New Paradigm in Branding Strategy, Journal of Marketing Communications, vol 14 no 1, 19-36.

10. Datta, P.R., Chowdhury, D.N. Chakaraborty, B.R., 2002, Viral Marketing: New Form of Word of Mouth Through Internet, The Business Review, vol 3 no 2, 69-75.
11. Gera, R., 2011, Modelling E-Service Quality and Its Consequences in India: An SEM Approach, Journal of Research in Interactive Marketing, vol 5 no 2/3, 203-225.

12. Gregg, D.G., Walczak, S., 2010, The Relationship Between Website Quality, Trust and Price Premiums at Online Auctions, Journal Electronic Commerce Research, vol 10 no 1, 1-25.

13. Ho, C.I., Lee, Y.L., 2007, The Development of An E-Travel Service Quality Scale, Tourism Management, vol 28, 1434-1449.

14. Kaura, V., Prasad, C.S.D., Sharma, S., 2015, Service Quality, Service Convenience, Price and Fairness, Customer Loyalty, and The Mediating Role of Customer Satisfaction,

15. International Journal of Bank Marketing, vol 33 no 4, 404-422.

16. Kiyani, T.M., Niazi, M.R.U.K., Rizvi, R.A., Khan, I., 2012, The Relationship Between Brand

17. Trust, Customer Satisfaction and Customer Loyalty (Evidence from Automobile Sector of Pakistan), Interdiscip. J. Contemp. Res. Bus., vol 4, 489-502.

How to cite this article: Muhammad Al Fikri. Enhance strategy promotion university of Medan area to increasing the number of new students during the COVID-19 pandemic. International Journal of Research and Review. 2021; 8(5): 432-437. DOI: https://doi.org/10. 52403/ijrr.20210553 